\title{
Potential Predictors of Timely Completion among Dissertation Research Students at an Australian Faculty of Sciences
}

\author{
Vladimir Jiranek \\ University of Adelaide, Adelaide, South Australia, Australia
}

vladimir.jiranek@adelaide.edu.au

\begin{abstract}
Successful and timely completion by Dissertation Research (DR) students (i.e. research Masters and $\mathrm{PhD}$ ) is increasingly important for students, supervisors, the university, and funding bodies alike. Previous studies highlight the importance of contributing factors, which can be classified according to their relating to the student, the supervisory arrangement, or the research infrastructure. However, the relative importance of specific factors for individual students can vary markedly across studies. In recognition of this fact, a survey of DR student completion rates and candidature duration within an Australian Faculty of Sciences (i.e. the author's home institution and broad field of research activity) was conducted. Available information was extracted for a 10-year window (1996-2006) from faculty-level and university-level databases and included data relating to demographics, field of study, attendance mode, scholarships held, and duration of candidature for up to 1688 students. The results suggest an attrition rate of $33 \%$ with shorter completion times being seen within the School of Chemistry \& Physics and among male and/or international students with scholarships. Possible predictors of HRD student success are considered, thereby beginning to provide a framework within which to develop practices to increase retention and completion rates in other areas of the faculty.
\end{abstract}

Keywords: Higher degree research, completion, attrition.

\section{Introduction}

The training of Doctoral and Masters research students (here referred to as Dissertation Research, [DR] students), collectively referred to as Higher Degree Research (HDR) students in Australia, is a core part of the activities of any research intensive university. Such students not only represent a cost-effective means for universities to achieve their research outputs, but are also an investment in the research capacity of the future. In Australia, the importance of DR students is recognized by the major national research funding body, the Australian Research Council (ARC). For the ARC, a key objective associated with the management and allocation of research funding

Material published as part of this publication, either on-line or in print, is copyrighted by the Informing Science Institute. Permission to make digital or paper copy of part or all of these works for personal or classroom use is granted without fee provided that the copies are not made or distributed for profit or commercial advantage AND that copies 1) bear this notice in full and 2) give the full citation on the first page. It is permissible to abstract these works so long as credit is given. To copy in all other cases or to republish or to post on a server or to redistribute to lists requires specific permission and payment of a fee. Contact Publisher@,InformingScience.org to request redistribution permission. is to "Contribute to high-quality research training and foster career opportunities for Australia's best and brightest researchers" (Australian Research Council, 2006). The current strategic plan of the ARC seeks to expand this capacity further (Australian Research Council, 2008). Despite this importance, and the investment of considerable resources by the host university, the train- 
ing of DR students is a problematic undertaking and not all students complete in a timely manner, if at all.

Apart from the failure of the students to fulfill their study and career aspirations, the implications of protraction or non-completion are numerous: i) the research program and future funding bids of the supervisor may be compromised, ii) losses to the University associated with the recruitment and provision of necessary research infrastructure and supervision are substantial, iii) the earnings of the university through the Australian Federal Government's Research Training Scheme (worth tens of millions per year for many Australian universities) may be reduced since these are in part determined by DR completions, and iv) through their contribution to various rankings for universities (e.g. "Australia's Good Universities Guide," 2009), DR completions and student satisfaction are becoming increasingly important in attracting students in an highly competitive, international, tertiary education sector.

Reports of attrition rates are numerous and differing, ranging from lows of 10-20\% to an apparent extreme of approximately 85\% (reviewed by Bourke, Holbrook, Lovat, \& Farley, 2004). From such studies, it is clear that these values are subject to a number of variables. Thus, when considering the discipline area, the arts and humanities generally see higher attrition rates (45-51\%), while the sciences observe rates of $30-40 \%$ (Elgar, 2003; Martin, Maclachlan, \& Karmel, 1999; Wright \& Cochrane, 2000). Regardless of the precise value, it is doubtful that students, universities, and governments alike would find these figures acceptable. Of course, the reasons behind slow or non-completing DR candidates are numerous and complex.

In Australia, the path to a $\mathrm{PhD}$ from an undergraduate degree typically occurs via a research Honours degree. The latter may be a distinct, one-year add-on after an undergraduate degree of three or more years, or it may be incorporated into a four year undergraduate degree. In some cases, a research Masters degree may be undertaken in place of or after the Honours degree. In reality, the vast majority of Masters candidates will, after their first year of study, upgrade to a $\mathrm{PhD}$ program. Therefore a Masters is a relatively uncommon exit point for Australian students. Since the Honours and/or Master degrees often comprise some coursework, it is usual for the $\mathrm{PhD}$ program to be entirely research-based and include course work only if a specific shortfall in the candidate's background has been identified early in the candidature. $\mathrm{PhD}$ students are expected to submit their thesis within $3-4$ years of full-time study. Increasingly, scholarships for full-time MSc or $\mathrm{PhD}$ study are only available for 2 or 3 years, respectively, with the possibility of a 6-month extension in some cases.

It is important to recognize that the higher degree is inherently challenging as predicated on the fact that the work must result in a significant original contribution to knowledge in the chosen discipline. In the Sciences a DR student is directly involved in research at the frontiers of current knowledge - essentially uncharted waters with no guarantee of (technical) success. While anecdotal evidence suggests that serious technical difficulties are one common reason for candidature to be protracted, such failures need to be catastrophic before a student does not complete at all. Beyond such failures, a review of the literature suggests there are 3 groups of factors which contribute to timely DR completion (Figure 1). These are: 1) the quality and personal situation of the student including academic ability, financial situation, language skills, interpersonal skills, and persistence $v s$ so-called self-sabotaging behaviors (reviewed by Kearns, Gardiner, \& Marshall, $2008), 2$ ) the nature and quality of supervision, including frequency of meetings, support from other students and research colleagues, and 3) the resources and facilities available to the project (e.g., culture collections, analytical facilities, necessary expertise, etc.). Without all components there is greater likelihood that the project collapses. Which factors are most important in determining attrition or completion vary by the individual setting of each student and are further complicated by the interconnectedness of the three classes of factors (reviewed by Wright, 2003). Nevertheless, in order to facilitate timely DR completion contributing factors must be identified. 
In their study of 3579 DR students working towards a $\mathrm{PhD}$ between 1984 and 1993 in the UK, Wright and Cochrane (2000) considered gender, age, faculty cluster (e.g. Sciences $v s$ Arts), part-time $v s$ full-time study modes, student origin, source of funding, class of first degree, and whether the students were graduates from within the host university. Key findings were that students most likely to submit their thesis within the 4 years were those that were studying a science-based subject, had a high grade first degree, held research funding and, interestingly, were international and studying part-time. Gender appeared unimportant, as found previously by Seagram, Gould, and Pyke (1998).

The PhD Completion Project, undertaken by the Council of Graduate Schools (2008), examined PhD completion rates after 7 and 10 years for some 19,000 students from 24 North American institutions. The data reiterated the tendency for higher completion rates to be seen among students in the Sciences, Engineering, and Mathematics fields. Some gender and ethnicity effects were evident in this study, as were effects due to citizenship (i.e. domestic $v s$. international). In a subset of data from this project derived from Duke University (Siegel, 2005), high entrance scores were seen to predict success, while support in the form of mentoring and financial aid was also important. At a prestigious school, all entrance scores were considered high, hence factors such as the quality of the student-advisor relationship and the opportunity of the student to integrate into the academic and social life of the institution were highlighted through interviews with 20 mathematics doctoral students (Earl-Novell, 2006). In a study of Information System doctorates, the extent to which the student felt a sense of isolation, was identified as a key cause of attrition and provided the impetus for development of a targeted solution which contributed to a higher than average graduation rates (Ali \& Kohun, 2006; 2007).

Equivalent, comprehensive studies are not available for Australian universities. In his commentary on experiences at the Australian National University (ANU) including 150 confidential exit interviews with students between 1994 and 1998, Spear (1999) concluded that the graduate experience at ANU was "strongly positive." In their 1999 report, Martin et al. provided a snapshot of the progress of 5552 non-overseas DR students who commenced in 1992 in one of 34 Australian institutions. Completion rates were similar for males and females, and higher for full-time and younger (i.e. $<24$ years of age) students. An important conclusion from this study was that a significant proportion of the variation in predicted completion rates was explained by university specific factors (Martin et al., 1999). With these rates of completion ranging between 20 and $66 \%$, it is clear that local data will be an essential part of the attempts of any institution and faculty, if not department, to improve completion rates of its own DR students. In defining the parameters linked with timely completion, slow completion and attrition, it will further be possible to determine which attributes of students, the supervisory arrangement, and the resourcing of the DR program are linked with success and which are not. The ultimate goals are to define more appropriate resourcing levels, better criteria for selection of students or, as reported recently (Manathunga, 2005), the development of localized strategies for improving the retention of students experiencing difficulties.

This study attempts to provide such data for DR students in the Faculty of Sciences at the University of Adelaide across a 10-year period spanning 1996-2006. Parameters considered include completion rates, candidature duration, amount of leave taken, the school with which the students 
were associated, their gender, age at enrolment, country of birth, and designation as domestic or international students.

\section{Method}

\section{Data Sources}

Data used in this study were extracted (as tab delimited files) from two key information systems $\left(\right.$ PeopleSoft $^{\mathbb{R}}$ and Data Warehouse ${ }^{\mathbb{B}}$ ) in use by the University of Adelaide at the time when this information was collected between May $11^{\text {th }}$ and October $23^{\text {rd }}, 2006$. A total of 1688 unique entries were found for the Faculty of Sciences across the merged datasets. Entries were imported into Microsoft Office Excel 2003 wherein they were sorted and the required statistics gathered for the headings detailed in the Results section. At the conclusion of any sorting exercise a random selection (typically 6 entries) was checked for completeness and absence of errors. Entries included information under one or more of the following headings: Student ID number, date of birth, gender, domestic $v s$. international status, country of birth, full-time $v s$. part-time attendance, department and school, candidature/scholarship start date, submission date, completion date and leave taken.

\section{Limitations}

Approximately $20 \%$ of entries contained values under all of the above headings. In several instances multiple entries were missing. Thus for some students who had completed, no dates were available for the start of candidature, submission of a thesis, or completion of degree requirements. Where a specific start date was lacking, a nominal semester start date of either March $1^{\text {st }}$ or August $1^{\text {st }}$ was adopted according to other indications of the commencement semester. Similarly, in instances where a thesis submission date was recorded but a completion date was not, an average value for the time elapsing between thesis submission and completion (designated the 'revision time') was calculated from available information and applied to incomplete entries. While it is recognized that in some cases the absence of a completion date is a genuine reflection of a failure of the student to satisfactorily complete the revision of an examined thesis or otherwise meet the requirement of the award, these cases are likely to be rare. Where insufficient data, from any source was available to justify retention of the student in an analysis under a given parameter/heading, the entry was excluded. This allowed the maximum number of students to be considered in each case, however, it meant that the totals reported across the results tables and figures were not necessarily the same.

\section{Results}

\section{Demographics}

At the time that data for this study were gathered, records existed for 1688 higher degree research (DR) students, which included both MSc and PhD programs. Students initially enrolled in MSc programs and for whom there existed evidence of upgrade to a $\mathrm{PhD}$, were treated as $\mathrm{PhD}$ students. A further $139 \mathrm{MSc}$ students were clearly identified as such and are so labeled throughout this study, while another 484 had no program recorded but were treated as $\mathrm{PhD}$ students. Again the latter assumption is based on the fact that few $(\sim 8 \%)$ MSc students actually complete this degree, with the vast majority converting to $\mathrm{PhD}$ candidature as this is the preferred higher degree for DR students in Australia.

The distribution of a total of 1688 DR entries across the five key areas of the Faculty of Sciences at the University of Adelaide is shown in Table 1. Of the students with an identified degree, the 
vast majority (92\%) were enrolled in a $\mathrm{PhD}$ as their terminal degree. With some $30 \%$ each of the total, most DR students were enrolled through the Schools of Earth \& Environmental Sciences (E\&ES) and Molecular \& Biomedical Science (M\&BS). The Schools of Agriculture, Food \& Wine (AF\&W) and Chemistry \& Physics (C\&P) each enrolled about 20\% with the remaining 3\% of DR students enrolled through the Australian School of Petroleum (ASP).

Table 1: Distribution of DR students by program across the Schools of the Faculty of Sciences.

\begin{tabular}{|r|c|c|c|c|}
\hline \multicolumn{1}{|c|}{ SCHOOL $^{1}$} & UNIDENTIFIED & PhD $^{\mathbf{2}}$ & MSc & TOTAL \\
\hline Aust. Schl. Petrol. & $16(3)$ & $22(3)$ & - & $38(3)$ \\
\hline Ag., Food \& Wine & $81(17)$ & $149(22)$ & $4(17)$ & $234(20)$ \\
\hline Chem. \& Phys. & $88(19)$ & $101(15)$ & $4(17)$ & $193(16)$ \\
\hline Earth \& Environ. Sci. & $148(32)$ & $214(31)$ & $13(57)$ & $375(32)$ \\
\hline Molec. \& Biomed. Sci. & $137(29)$ & $199(29)$ & $2(9)$ & $338(29)$ \\
\hline Unknown & 14 & 380 & 116 & 510 \\
\hline Total & $\mathbf{4 8 4}$ & $\mathbf{1 0 6 5}$ & $\mathbf{1 3 9}$ & $\mathbf{1 6 8 8}$ \\
\hline
\end{tabular}

Current School names (includes data from previous school name/structure iterations). ${ }^{2}$ Includes students who upgraded from an MSc. Values in brackets represent the percentage of the column total.

Table 2: DR student demographics by School within the Faculty of Sciences.

\begin{tabular}{|c|c|c|c|c|c|c|c|c|c|}
\hline \multirow[t]{2}{*}{ SCHOOL } & \multirow[t]{2}{*}{$\begin{array}{l}\text { DOMES- } \\
\text { TIC }\end{array}$} & \multirow[t]{2}{*}{$\begin{array}{l}\text { INTERNA- } \\
\text { TIONAL }\end{array}$} & \multirow[t]{2}{*}{ MALE } & \multirow[t]{2}{*}{$\begin{array}{c}\text { FE- } \\
\text { MALE }\end{array}$} & \multicolumn{5}{|c|}{$\begin{array}{c}\text { AGE AT ENROLMENT } \\
\text { (YR) }\end{array}$} \\
\hline & & & & & $<24$ & $24-34$ & $35-44$ & $45-54$ & $>54$ \\
\hline Aust. Schl. Petrol. & 18 & 4 & $16(67)$ & $6(33)$ & 10 & 10 & 1 & 1 & 0 \\
\hline Ag., Food \& Wine & 134 & 17 & $66(44)$ & $85(56)$ & 56 & 73 & 17 & 5 & 0 \\
\hline Chem. \& Phys. & 97 & 8 & $72(69)$ & $33(31)$ & 70 & 31 & 4 & 0 & 0 \\
\hline Earth \& Environ. Sci. & 206 & 16 & $133(60)$ & $89(40)$ & 55 & 126 & 30 & 11 & 0 \\
\hline Molec. \& Biomed. Sci. & 187 & 14 & $86(43)$ & $115(57)$ & 125 & 62 & 11 & 3 & 0 \\
\hline Unknown & 263 & 232 & $299(60)$ & $197(40)$ & 21 & 40 & 23 & 5 & 1 \\
\hline Total & 905 & 291 & 672 & 525 & 337 & 342 & 86 & 25 & 1 \\
\hline
\end{tabular}

Values in brackets represent the percentage represented by each gender for a given School.

Other available demographic information for the DR student entries is summarized in Table 2. For those students for whom a classification was entered $(n=1196), 24.3 \%$ were international. Of the remaining $75.7 \%$ designated as domestic students, most were citizens of Australia $(92.5 \%)$ or New Zealand (2.2\%) or permanent residents of Australia (5.3\%). Again for the students so identified across the entire Faculty of Sciences $(n=1197), 56.1 \%$ were male and $43.9 \%$ were female. Schools where female students predominated include AF\&W and M\&BS (Table 2). Overall, students were most commonly less than 35 years of age (i.e. $43 \%$ were $<24$ yrs and $43 \%$ were $25-34 \mathrm{yrs}$ ). Students designated as international and for whom an entry for country of birth 
was recorded were distributed as detailed in Table 3. Both Asian and European countries were well represented overall but, typically, with only a small number or single students from specific countries.

Table 3: Country of birth for international DR students within the Faculty of Sciences.

\begin{tabular}{|l|l|l|l|l|l|l|l|}
\hline COUNTRY & NUMBER & COUNTRY & NUMBER & COUNTRY & NUMBER & COUNTRY & NUMBER \\
\hline Unknown & 137 & Japan & 4 & Burma & 1 & Oman & 1 \\
\hline Iran & 20 & UK & 4 & Canada & 1 & P.N.G & 1 \\
\hline China & 21 & Vietnam & 4 & Colombia & 1 & Poland & 1 \\
\hline India & 12 & Bangladesh & 3 & Croatia & 1 & Romania & 1 \\
\hline USA & 10 & Chile & 2 & Denmark & 1 & Russian Fed. & 1 \\
\hline Indonesia & 10 & Korea & 2 & Egypt & 1 & Singapore & 1 \\
\hline Thailand & 8 & South Africa & 2 & Eritrea & 1 & Sweden & 1 \\
\hline Malaysia & 5 & Sri Lanka & 2 & France & 1 & Switzerland & 1 \\
\hline Mexico & 5 & Taiwan & 2 & Italy & 1 & Tunisia & 1 \\
\hline Pakistan & 5 & Argentina & 1 & Jordan & 1 & Uganda & 1 \\
\hline Saudi Arabia & 5 & Austria & 1 & Netherlands & 1 & & \\
\hline Germany & 4 & Belgium & 1 & Nigeria & 1 & TOTAL & 292 \\
\hline
\end{tabular}

\section{Completion Trends and Candidature Durations}

Even within the assumptions made for students where a completion date was not indicated (see Methods), completion rates were well below $100 \%$. Clearly, in the cases where commencement occurred in more recent years it is likely that such students were still actively engaged in research and perhaps were still within the initial candidature time. Conversely, for those who commenced before mid-2002 and could be reasoned to have had sufficient time to complete by the 2006 date of this census (assuming a typical $\mathrm{PhD}$ completion time of approximately 4 years), only $50 \%$ of students with specified start dates $(n=480)$ had a recorded completion date and therefore were deemed completed. It is likely that actual completion rates are higher and that completion details for some are were yet to be entered.

For students for which commencement and submission or completion dates were recorded (i.e. up to 376 students) it was possible to calculate total candidature times. Across the Faculty of Sciences, the average time to submission of the thesis was 4.3 years (Table 4). Averages for individual Schools were of a similar duration with two exceptions: C\&P showed a reduced time of 4.0 years, while submissions in ASP took an additional 12 months. The latter value should be considered with caution as it is based on 4 individuals only. Differences were also seen in the time to thesis submission according to gender such that males required 4.1 years compared with 4.5 years for females. Similarly international students submitted after 3.9 years compared to 4.4 years for domestic students. In all cases, revision time was similar with a Faculty average of 0.4 of a year (approx. 5 months). 
Table 4: PhD student submission, completion and leave durations by School, gender and mode of study for students with and without scholarships ${ }^{1}$.

\begin{tabular}{|c|c|c|c|c|c|}
\hline SCHOOL & $\begin{array}{c}\text { AVERAGE } \\
\text { YEARS TO } \\
\text { SUBMISSION }\end{array}$ & $\begin{array}{l}\text { AVERAGE } \\
\text { YEARS REVI- } \\
\text { SION TIME }\end{array}$ & \begin{tabular}{c|} 
AVERAGE \\
YEARS TO \\
COMPLETION
\end{tabular} & $\begin{array}{l}\text { AVERAGE } \\
\text { YEARS } \\
\text { LEAVE }\end{array}$ & $\begin{array}{l}\text { YEARS TO COM- } \\
\text { PLETION (LESS } \\
\text { LEAVE) }\end{array}$ \\
\hline $\begin{array}{r}\text { Aust. Schl. } \\
\text { Petrol. }\end{array}$ & $\begin{array}{c}5.3 \\
(n=4)\end{array}$ & $\begin{array}{c}0.4 \\
(\mathrm{n}=1)\end{array}$ & $\begin{array}{c}5.1 \\
(\mathrm{n}=7)\end{array}$ & $\begin{array}{c}0.1 \\
(\mathrm{n}=22)\end{array}$ & $\begin{array}{c}5.0 \\
(\mathrm{n}=7)\end{array}$ \\
\hline $\begin{array}{r}\text { Ag., Food \& } \\
\text { Wine }\end{array}$ & $\begin{array}{c}4.3 \\
(\mathrm{n}=47)\end{array}$ & $\begin{array}{c}0.5 \\
(\mathrm{n}=40)\end{array}$ & $\begin{array}{c}4.9 \\
(\mathrm{n}=55)\end{array}$ & $\begin{array}{c}0.2 \\
(\mathrm{n}=149)\end{array}$ & $\begin{array}{c}4.8 \\
(\mathrm{n}=55)\end{array}$ \\
\hline $\begin{array}{r}\text { Chem. \& } \\
\text { Phys. }\end{array}$ & $\begin{array}{c}4.0 \\
(\mathrm{n}=50)\end{array}$ & $\begin{array}{c}0.3 \\
(\mathrm{n}=38)\end{array}$ & $\begin{array}{c}4.3 \\
(\mathrm{n}=51)\end{array}$ & $\begin{array}{c}0.1 \\
(\mathrm{n}=101)\end{array}$ & $\begin{array}{c}4.1 \\
(n=51)\end{array}$ \\
\hline $\begin{array}{r}\text { Earth \& } \\
\text { Environ. Sci. }\end{array}$ & $\begin{array}{c}4.3 \\
(\mathrm{n}=78)\end{array}$ & $\begin{array}{c}0.4 \\
(\mathrm{n}=65)\end{array}$ & $\begin{array}{c}4.7 \\
(\mathrm{n}=95)\end{array}$ & $\begin{array}{c}0.2 \\
(\mathrm{n}=214)\end{array}$ & $\begin{array}{c}4.6 \\
(n=95)\end{array}$ \\
\hline $\begin{array}{r}\text { Molec. \& } \\
\text { Biomed. Sci. }\end{array}$ & $\begin{array}{c}4.4 \\
(\mathrm{n}=87)\end{array}$ & $\begin{array}{c}0.4 \\
(\mathrm{n}=68)\end{array}$ & $\begin{array}{c}4.8 \\
(\mathrm{n}=95)\end{array}$ & $\begin{array}{c}0.2 \\
(\mathrm{n}=199)\end{array}$ & $\begin{array}{c}4.7 \\
(\mathrm{n}=95)\end{array}$ \\
\hline All & $\begin{array}{c}4.3 \\
(n=268)\end{array}$ & $\begin{array}{c}0.4 \\
(n=212)\end{array}$ & $\begin{array}{c}5.0 \\
(n=303)\end{array}$ & $\begin{array}{c}0.2 \\
(n=685)\end{array}$ & $\begin{array}{c}4.6 \\
(n=303)\end{array}$ \\
\hline \multicolumn{6}{|l|}{ GENDER } \\
\hline Male & $\begin{array}{c}4.1 \\
(\mathrm{n}=144)\end{array}$ & $\begin{array}{c}0.4 \\
(\mathrm{n}=111)\end{array}$ & $\begin{array}{c}4.5 \\
(\mathrm{n}=144)\end{array}$ & $\begin{array}{c}0.1 \\
(\mathrm{n}=144)\end{array}$ & $\begin{array}{c}4.4 \\
(\mathrm{n}=144)\end{array}$ \\
\hline Female & $\begin{array}{c}4.5 \\
(\mathrm{n}=121)\end{array}$ & $\begin{array}{c}0.4 \\
(\mathrm{n}=100)\end{array}$ & $\begin{array}{c}4.9 \\
(\mathrm{n}=121) \\
\end{array}$ & $\begin{array}{c}0.2 \\
(\mathrm{n}=121) \\
\end{array}$ & $\begin{array}{c}4.7 \\
(\mathrm{n}=121)\end{array}$ \\
\hline \multicolumn{6}{|c|}{ STUDENT TYPE } \\
\hline Domestic & $\begin{array}{c}4.4 \\
(\mathrm{n}=231)\end{array}$ & $\begin{array}{c}0.4 \\
(\mathrm{n}=180)\end{array}$ & $\begin{array}{c}5.1 \\
(\mathrm{n}=311)\end{array}$ & $\begin{array}{c}0.2 \\
(\mathrm{n}=625)\end{array}$ & $\begin{array}{c}4.6 \\
(n=264)\end{array}$ \\
\hline International & $\begin{array}{c}3.9 \\
(\mathrm{n}=36)\end{array}$ & $\begin{array}{c}0.3 \\
(\mathrm{n}=31)\end{array}$ & $\begin{array}{c}4.3 \\
(\mathrm{n}=64)\end{array}$ & $\begin{array}{c}0.1 \\
(\mathrm{n}=59)\end{array}$ & $\begin{array}{c}4.2 \\
(n=38)\end{array}$ \\
\hline \multicolumn{6}{|c|}{ SCHOLARSHIP } \\
\hline Yes & $\begin{array}{c}4.3 \\
(\mathrm{n}=265)\end{array}$ & $\begin{array}{c}0.4 \\
(\mathrm{n}=211)\end{array}$ & $\begin{array}{c}4.7 \\
(n=302)\end{array}$ & $\begin{array}{c}0.2 \\
(\mathrm{n}=682)\end{array}$ & $\begin{array}{c}4.6 \\
(n=302)\end{array}$ \\
\hline No & - & - & $\begin{array}{c}6.1 \\
(\mathrm{n}=74)\end{array}$ & $\begin{array}{c}0.1 \\
(n=4)\end{array}$ & - \\
\hline
\end{tabular}

${ }^{1}$ Includes those entries with an assumed completion date derived from an actual thesis submission date plus the average revision time. Durations for part-time students reduced by 2 -fold.

The average total time to completion (i.e. time elapsed since commencement) for the Faculty was 5 years, with most schools approaching this number (Table 5). C\&P was the exception with a time for completion of only 4.3 years. Gender differences were again evident with females taking approximately $11 \%$ longer than males who finished in 4.5 years. Similarly, international students completed in a total average time which was almost 10 months shorter than domestic students. Average time to completion was also the only data set for which it was possible to assess the impact of award of a scholarship (full or supplementary) on PhD progression. Thus, for the 302 students who held a scholarship during the course of their candidature, the average time that elapsed between commencement and completion was 4.7 years whereas the 74 students who did not receive a scholarship required 6.1 years to complete.

The further parameter to be considered in the context of completion time was the amount of leave taken. The values recorded correspond to leave above and beyond the permitted 20 days annual leave and are in fact periods of absence or intermissions of candidature. On average, such leave, which equated to between 0.1 and 0.2 of a year (i.e. 37 - 73 days), was taken by some 300 students. No marked trends were seen across Schools or demographic groups in terms of leave. As such, all average actual completion times (i.e. completion time minus any leave) were reduced by 
this average (Table 4). It is worthy of mention that there was no correlation $\left(R^{2}=0.001\right.$, data not shown) between age of the students at the commencement of study and the duration of candidature (less leave).

Table 5: Characteristics of leave (where taken) by PhD students within the Faculty of Sciences.

\begin{tabular}{|r|c|c|c|}
\hline \multicolumn{1}{|c|}{ SCHOOL } & $\begin{array}{c}\text { AVERAGE LEAVE } \\
\text { (DAYS) }\end{array}$ & $\begin{array}{c}\text { MINIMUM LEAVE } \\
\text { (DAYS) }\end{array}$ & $\begin{array}{c}\text { MAXIMUM LEAVE } \\
\text { (DAYS) }\end{array}$ \\
\hline Aust. Schl. Petrol. & $58(\mathrm{n}=16)$ & 8 & 190 \\
\hline Ag., Food \& Wine & $154(\mathrm{n}=63)$ & 1 & 1071 \\
\hline Chem. \& Phys. & $130(\mathrm{n}=39)$ & 3 & 1072 \\
\hline Earth \& Environ. Sci. & $160(\mathrm{n}=100)$ & 2 & 1798 \\
\hline Molec. \& Biomed. Sci. & $154(\mathrm{n}=82)$ & 1 & $\mathbf{1 7 9 8}$ \\
\hline All & $\mathbf{1 4 8}(\mathrm{n}=\mathbf{3 0 0})$ & $\mathbf{1}$ & 1072 \\
\hline GENDER Male & $115(\mathrm{n}=126)$ & 1 & 1798 \\
\hline Female & $179(\mathrm{n}=154)$ & 1 & 1798 \\
\hline STUDENT TYPE & $154(\mathrm{n}=280)$ & 1 & 508 \\
\hline Domestic & $62(\mathrm{n}=20)$ & 6 & \\
\hline International &
\end{tabular}

Given that recorded leave is additional to annual leave, any period taken may be considered an important interruption to progress of the candidate. From Figure 2 it can be seen that about one third of all cumulative periods of leave equated to less than 1 month. A further third extended from approximately 1 month to 3 months, with about $10 \%$ of leave taken in amounts which total between 1 year and nearly 5 years. The average period of leave taken across the 300 students against whom leave is recorded was 148 days. Marked deviations from this average were seen in ASP, which had an average of 58 days, and international students for whom the average was only 62 days. Female students took slightly longer leave (179 days) compared to males (115 days), but the values for the former include some instances of maternity leave. Consideration was given to the possible link between periods for leave and time to completion (less leave) but no correlation was found $\left(\mathrm{R}^{2}=0.102\right.$; data not shown).

The final parameter to be examined in this study was the average candidature duration across year of commencement. As can be seen from Figure 3, average candidature duration across the Faculty of Sciences was of the order of 6.9 years for students commencing in 1996 and who had completed. This value declined to a value of some 4 years for students commencing in 2001, and ultimately to about 3.7 years for students commencing in 2003. To estimate attrition rates, totals for completed and non-complete (or continuing) students were determined for the years 1996 to 2001. This interval was chosen as students commencing in 2002 or before will have had at least 5 years by the time this census was taken in 2006 to have completed their PhD. Accordingly, 139 students out of 420 had not completed, thereby yielding an apparent attrition rate of $33 \%$. 


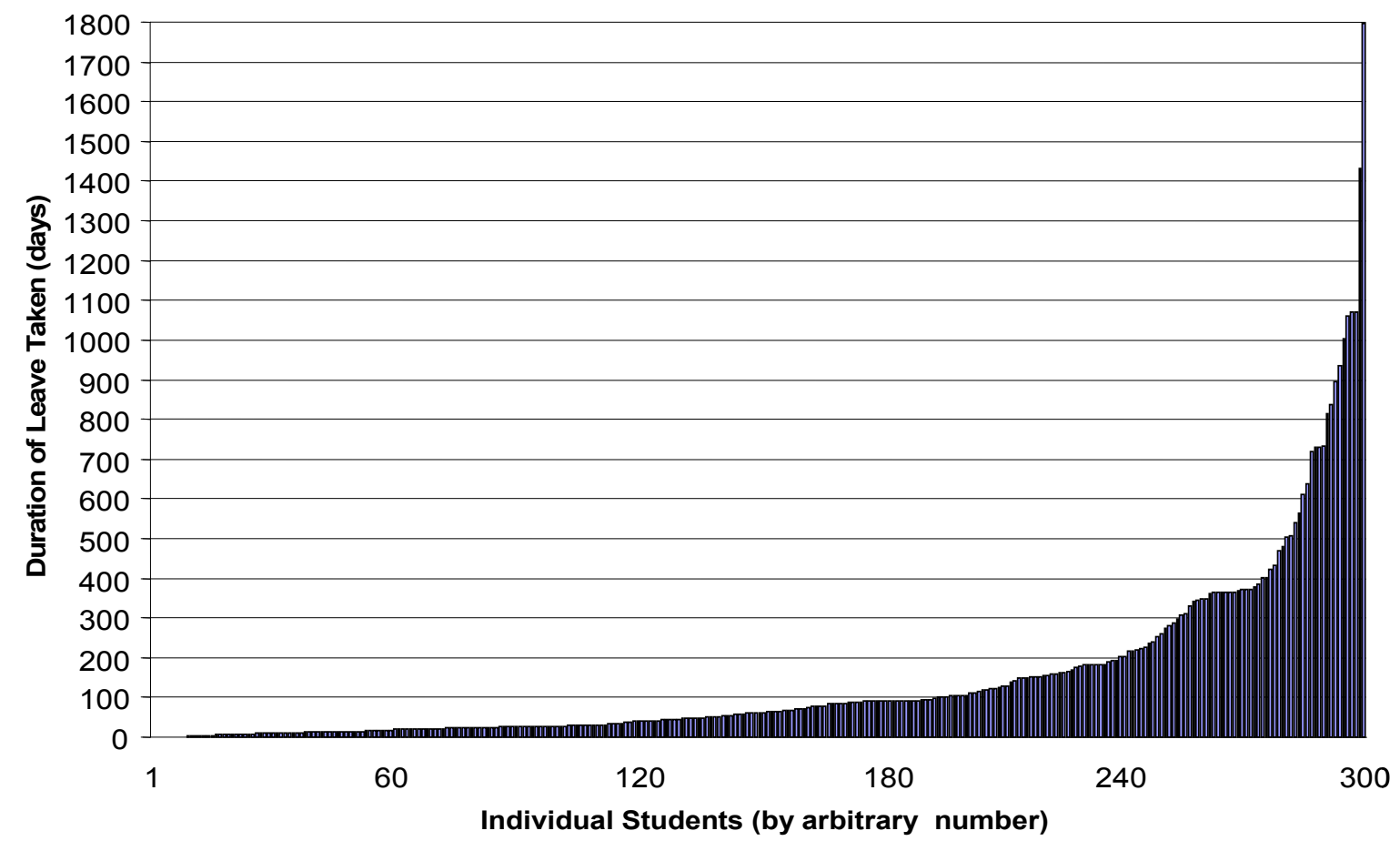

Figure 2: Histogram showing the cumulative duration of leave (excluding annual leave) for each of the 300 students for whom periods of leave were recorded.

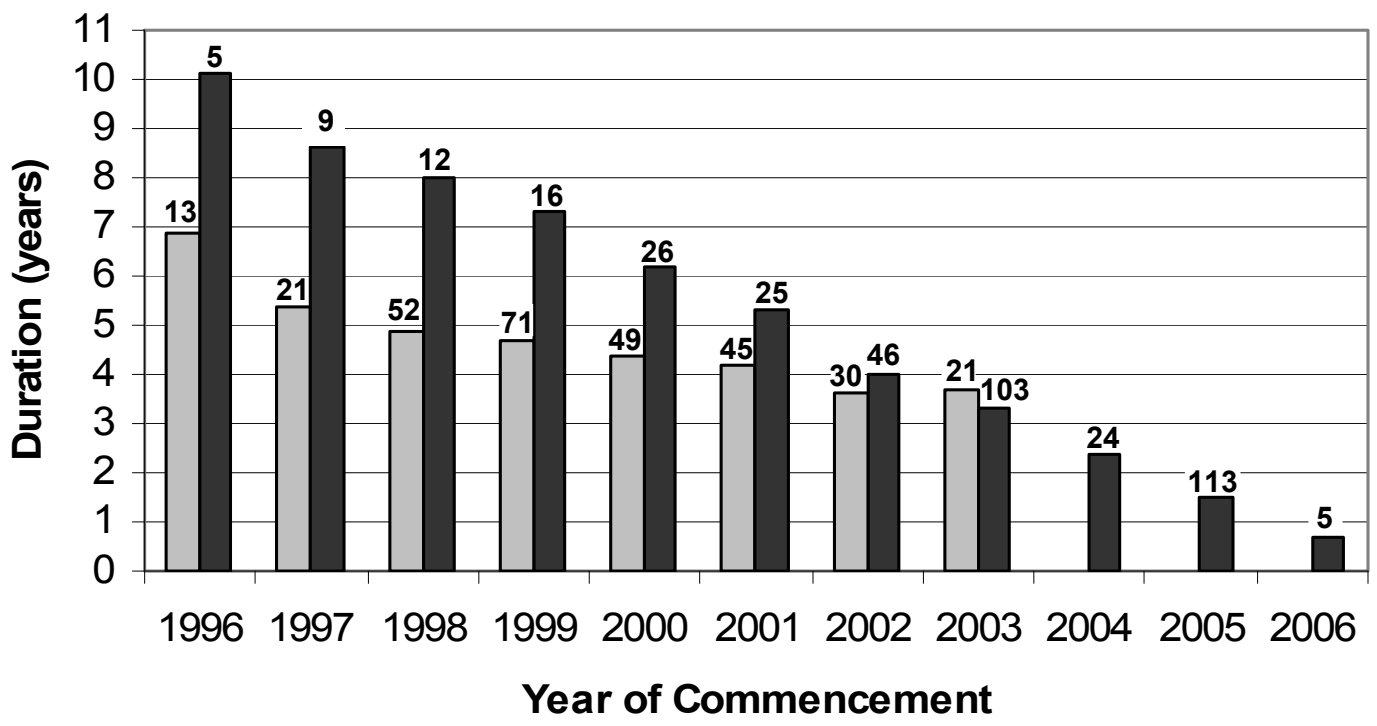

Figure 3: Histogram showing average candidature time (less leave) for PhD students who completed their degree ( $\square$ ) or were yet to complete ( $\square$ ) as of late 2006, as a function of year of commencement. Only students for whom accurate commencement dates and completion dates were recorder are included. Data for non-completed students is likely to include some instances of lapsed candidature which have not been recorded in the database. $\mathbf{N}=$ value above bars. 


\section{Discussion}

This longitudinal study of the DR student cohort of a Faculty of Science within Australia reports on the demographics and completion patterns of this population and reiterates the existence of significant attrition and suggests trends for particular groups/areas. Accurate estimates of attrition are difficult as students often do not formally withdraw or may in fact complete many years after commencing their studies. One approach therefore is to set a reasonable candidature duration as the basis for determining non-completion. In this study, 5 years was chosen, whereas others have used 7 or 10 year timeframes (Council of Graduate Schools, 2008). Here it can be seen that PhD students within the Faculty of Sciences exhibited an apparent attrition rate of $33 \%$ (i.e. 1/3 failed to complete within 5 years of commencement). This information alone is an important outcome of this study as it permits a degree of benchmarking. To that end it can be stated that the observed attrition rate is in the lower range of generic values reported previously (see review by Bourke et al., 2004) and comparable to rates determined specifically for the sciences (Elgar, 2003; Wright \& Cochrane, 2000). Reference to data from 34 Australian universities shows that an attrition rate of $33 \%$ over 5 years compares quite favorably with the national average of $47 \%$ even after 7 years (Martin et al., 1999).

Perhaps of greater interest are the trends seen in candidature duration as well as across discipline areas (Schools), gender, international vs. domestic students and those with or without scholarship support. Australian universities receive a fixed amount of funding for the completion of $\mathrm{PhD}$ students through the Research Training Scheme. No funds are forthcoming until the student has completed, and the amount allocated is fixed even if the student requires more time than the target of 4 years. Clearly a student taking 7 years to complete, for example, is likely to require greater resources which will not be compensated for by the RTS contribution. Timely completion is therefore essential. Consequently, practices which encourage or allow timely completion in this faculty are of great interest. As such, the attributes of $\mathrm{PhD}$ students with the School of Chemistry and Physics, who are able to complete in a candidature time (excluding leave) of 4.1 years compared to a faculty average of 4.6 years are of great interest. Further investigation will be required to determine which of the 3 broad factors, i.e. student attributes, supervision or infrastructure, contributed to the success of these students. At this stage, however, it can be stated that these values compare well with 3.9 years reported by Bourke et al. (2004) for Science PhD students at another Australian university.

While Wright and Cochrane (2000) and Seagram et al. (1998) found little difference in completion rates with regard to gender, in other studies, completion rates were around $10 \%$ higher among males (Council of Graduate Schools, 2008; Siegel, 2005) or predicted to be 3\% higher for females (Martin et al., 1999). In the present study, males were seen to complete quicker than females, i.e. 4.4 years compared to 4.7 years. While these values exclude any periods of extended leave, it is worth noting that females, on average, took more leave (179vs. 115 days) during their candidature. Although it might be reasoned that the amount of leave taken could be linked to the extent to which personal issues adversely impact on progress of the $\mathrm{PhD}$, there was not significant correlation between amount of leave and cumulative candidature duration. Extended leave does not therefore appear to be an indication that the student is having difficulties and may not complete in a timely manner. Instead, the extended leave by female students, which in some cases includes maternity leave, may result in their candidature experiencing greater disruption whereby resumption of their pre-leave rate of research and ultimate completion is slower.

Whether the students were international or domestic and how this affected candidature duration also proved to be of interest. International students completed quicker (4.2 vs. 4.6 years). In contrast, Wright and Cochrane (2000) found no difference between local and overseas students, whereas completion rates were $10 \%$ higher for international students in the USA (Council of Gradu- 
ate Schools, 2008). That international students have been shown to complete quicker may be attributable to several possibilities. Admission into programs for international students is often more competitive than for domestic students and hence the former cohort may, at least in part, be of a higher academic standard. Alternatively, the stay of an international student in the host country is often limited due to visa restrictions. As such, these students may be under much greater pressure to complete within the timeframe stipulated for the program.

The final parameter that was examined in this study related to whether or not students held a scholarship. Those that did completed about $25 \%$ sooner (4.7 years vs. 6.1 years) than students without a scholarship. At least two explanations may be put forward for this difference. Students who succeed in attracting scholarships are likely to have a better academic record; hence they are likely to be higher caliber students who are more likely to succeed. Alternatively, students without scholarships may be required to work longer hours in paid employment to support themselves (James, Bexley, Devlin, \& Marginson, 2007), thereby detracting from work towards their PhDs.

\section{Conclusion}

From the data reported here for one Faculty of Sciences, several parameters have been highlighted through their association with students who completed their $\mathrm{PhD}$ in a timely manner. Such students are likely to be in the School of Chemistry and Physics, be male, international students who hold a scholarship. The latter two parameters suggest that this cohort of students are likely to have been subject to more stringent selection criteria and/or to be under greater pressure to complete within a given timeframe. Consequently, it could be argued that entry requirements for domestic $\mathrm{PhD}$ students should be increased and stricter candidature times should be applied. With regard to the former a first or upper second class first degree has been shown to enhance completion rates by some $8 \%$ (Wright \& Cochrane, 2000). The application of finite and widely promoted candidature times could easily be implemented on a trial basis for evaluation. The notion of a finite candidature time followed by a financial disincentive is something which has recently been explored and found to be effective in some cases. Garibaldi, Giavazzi, Ichino, and Rettore (2007) report that a $€ 1000$ increase in the continuation tuition fee resulted in a $6 \%$ decrease in the probability of late graduation. Of course, such disincentives will be less effective for students for whom the delay in completion is not under the own control.

Apart from the above parameters, some of which warrant further investigation, there are others for which the data should be collected so that their impact might be considered in the future. Such parameters include student attributes (i.e. academic record, English language proficiency, communication skills, disabilities, number of dependents, financial situation, support from friends and family, etc), research infrastructure (i.e. extent to which the research/study facilities fulfill the needs of the project, project funding, access to key equipment or facilities, travel support or funding to access specialist facilities, library and computing facilities, etc) and supervisory arrangements (i.e. nature, frequency and effectiveness of supervisory meetings, nature of student induction program, supervisor experience, involvement of student in presentations/publications, introduction to and interaction with peers, etc). Such data could be readily collected through questionnaires or interviews of individual students as described by other researchers (Ali \& Kohun, 2007; Earl-Novell, 2006) or via further interrogation of institutional databases. With this information at hand an institution will be better placed to evaluate the extent to which all aspects of the "DR completion triangle" (Figure 1) are being supported. While some of these areas, if shown to be lacking, may be easily addressed by the institution, others relating to student and supervisor abilities and psychologies may be more complex. Even so, some promising inroads are being made in these areas (Kearns et al., 2008; Marsh, Rowe, \& Martin, 2002; Wright, 2003). Improvements in $\mathrm{PhD}$ completions and the quality of the $\mathrm{PhD}$ experience for students, supervisors and the host institution therefore seem achievable. 


\section{References}

Australia's Good Universities Guide. (2009). University Ratings. Retrieved May 4, 2009, from, http://www.gooduniguide.com.au

Ali, A., \& Kohun, F. (2006). Dealing with isolation feelings at IS doctoral programs. International Journal of Doctoral Studies, 1, 21-33. Retrieved September 14, 2009 from http://ijds.org/Volume1/IJDSv1p021-033Ali13.pdf

Ali, A., \& Kohun, F. (2007). Dealing with social isolation to minimize doctoral attrition - A four stage framework. International Journal of Doctoral Studies, 2, 33-39. Retrieved September 14, 2009 from http://ijds.org/Volume2/IJDSv2p033-049Ali28.pdf

Australian Research Council. (2006). ARC Strategic Plan 2006-2008. Retrieved May 4, 2009 from http://www.arc.gov.au/pdf/ARC_Strategic_Plan06-08.pdf

Australian Research Council. (2008). ARC Strategic Plan 2008-09 to 2010-11. Retrieved May 4, 2009, from http://www.arc.gov.au/pdf/ARC_Strategic_Plan08-11.pdf

Bourke, S., Holbrook, A., Lovat, T., \& Farley, P. (2004, November). Attrition, completion and completion times of PhD candidates. Australian Association for Research in Education Conference, Melbourne, Australia, 1-14. Retrieved May 4, 2009 http://www.aare.edu.au/04pap/bou04849.pdf

Council of Graduate Schools. (2008) Ph.D. Completion and attrition: Analysis of baseline demographic data from the Ph.D. completion project. Washington: DC.

Earl-Novell, S. (2006). Determining the extent to which program structure features and integration mechanisms facilitate or impede doctoral student persistence in mathematics. International Journal of Doctoral Studies, 1, 45-57. Retrieved September 14, 2009 from http://www.ijds.org/Volume1/IJDSv1p045-057Earl16.pdf

Elgar, F. (2003). PhD completion in Canadian universities. Final report. Halifax, Nova Scotia: Graduate Students Association of Canada. Retrieved May 12, 2009 from http://careerchem.com/CAREERINFO-ACADEMIC/Frank-Elgar.pdf

Garibaldi, P., Giavazzi, F., Ichino, A., \& Rettore, E. (2007). College cost and time to complete a degree: Evidence from tuition discontinuities. NBER Working Paper No. W12863. Social Science Research Network. Retrieved May 12, 2009 from http://ssrn.com/abstract=959137

James, R., Bexley, E., Devlin, M., \& Marginson, S. (2007). Australian university student finances 2006: Final report of a national survey of students in public universities. Retrieved May 12, 2009 from http://www.universitiesaustralia.edu.au/documents/publications/policy/survey/AUSF-Final-Report2006.pdf

Kearns, H., Gardiner, M., \& Marshall, K. (2008). Innovation in PhD completion: The hardy shall succeed (and be happy!). Higher Education Research \& Development, 27, 77-89.

Manathunga, C. (2005). Early warning signs in postgraduate research education: A different approach to ensuring timely completions. Teaching in Higher Education, 10, 219 - 233.

Marsh, H. W., Rowe, K. J., \& Martin, A. (2002). PhD students' evaluations of research supervision: Issues, complexities, and challenges in a nationwide Australian experiment in benchmarking universities. The Journal of Higher Education, 73, 313-348.

Martin, Y. M., Maclachlan, M., \& Karmel, T. (1999). Postgraduate completion rates. Department of Education, Training and Youth Affairs. Retrieved May 12, 2009 from http://www.dest.gov.au/archive/highered/occpaper/01d/01d.pdf

Seagram, B. C., Gould, J., \& Pyke, S. W. (1998). An investigation of gender and other variables on time to completion of doctoral degrees. Research in Higher Education, 39, 319-335.

Siegel, L. (2005) A study of Ph.D. completion at Duke University. CGS Communicator, XXXVIII(1), $1,2,6,7$. 
Spear, R. H. (1999). The PhD experience at the Australian National University. Occassional Paper GS 99/2, Australian National University. Retrieved June 5, 2007 from http://www.anu.edu.au/graduate/pubs/occasional papers/GS99_2.pdf

Wright, T. (2003). Postgraduate research students: People in context? British Journal of Guidance \& Counselling, 31, 209-227.

Wright, T., \& Cochrane, R. (2000). Factors influencing successful submission of PhD Theses. Studies in Higher Education, 25, 181-195.

\section{Biography}

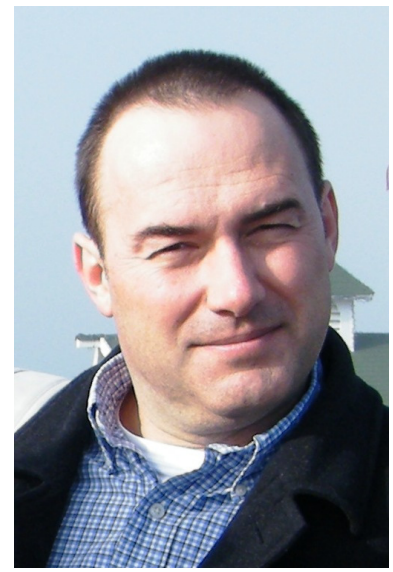

Vladimir Jiranek, Ph.D., is an Associate Professor in Oenology at the University of Adelaide. He holds a doctorate for studies in wine microbiology from the same university where he also earned a Graduate Certificate in Education (Higher Education). Dr Jiranek heads a large research group working in the field of microbial biotechnology. The group comprises several local and international Ph.D. students and consequently, Dr Jiranek has great personal interest in assisting students to complete their degrees and go on to succeed in independent research positions. Dr Jiranek has also held the role of Program Advisor for the university's undergraduate oenology and biotechnology degrees and recently took up the role of Associate Dean for Postgraduate Coursework within the Faculty of Sciences. 